\title{
Elasmobranch spatial segregation in the western Mediterranean
}

\author{
ADAM GOURAGUINE ${ }^{1,2}$, MANUEL HIDALGO $^{3}$, JOAN MORANTA $^{1}$, \\ DAVID M. BAILEY ${ }^{2}$, FRANCESC ORDINES ${ }^{1}$, BEATRIZ GUIJARRO ${ }^{1}$, MARÍA VALLS ${ }^{1}$, \\ CARMEN BARBERÁ ${ }^{1}$ and AINA DE MESA ${ }^{1}$ \\ ${ }^{1}$ Instituto Español de Oceanografía, Centre Oceanogràfic de les Balears, Moll de Ponent s/n, 07015 Palma, Spain. \\ E-mail: joan.moranta@ba.ieo.es \\ ${ }^{2}$ University of Glasgow, Division of Ecology and Evolutionary Biology, Graham Kerr Building, Glasgow G12 8QQ, \\ United Kingdom. \\ ${ }^{3}$ Centre for Ecological and Evolutionary Synthesis (CEES), Department of Biology, University of Oslo, PO Box 1066 \\ Blindern, 0316 Oslo, Norway.
}

\begin{abstract}
SUMMARY: Basic information on the distribution and habitat preferences of ecologically important species is essential for their management and protection. This study focuses on the depth related trends and the geographic patterns that shape the community of the elasmobranch species in the Balearic Islands (Mediterranean Sea) using data collected from 2001 to 2009. Non-metric Multi-Dimensional Scaling (MDS) ordination was used to detect zonation patterns in the community. Generalized Additive Models (GAMs) were applied to analyse spatial and temporal variation in elasmobranch community descriptors (abundance, biomass, mean fish weight, number of species and diversity), as well as the abundance and mean length of the four individual species ( $S$. canicula, G. melastomus, $R$. clavata, $R$. miraletus). Depth was the main factor determining the assemblage composition, and the MDS analysis identified four main groups with $60 \%$ of the similarity found to correspond to the continental shelf, shelf break, upper slope and middle slope of the surveyed area. GAM analysis identified spatial patterns that were independent of the bathymetric distribution preference. Although depth was a strong predictor for all the analyses performed, the geographic variation in the elasmobranch abundance was also important. The results also show a reduction in the mean length of the elasmobranch species in the areas with high fishing intensity. Our study evidences a clear spatial segregation of the main species throughout the ontogeny because the geographic and bathymetric effects were highly size dependent, with clear differences between the bathymetric distributions of juveniles and adults but no clear spatial overlapping. This study sheds new light on the spatial distribution of the elasmobranch species off the Balearic Islands, which is essential information for protecting marine organisms along with their habitats and promoting ecosystem based management.
\end{abstract}

Keywords: Elasmobranch, Balearic Islands, GAM, MDS, community descriptors, species distribution, bathymetric patterns, spatial segregation, fishing impact.

RESUMEN: Segregación espacial de elasmobranquios en el Mediterráneo occidental. - El conocimiento sobre la distribución y los hábitats preferentes de las especies clave del ecosistema es esencial para su gestión y protección. Este estudio se centra en el análisis de las tendencias batimétricas y los patrones de distribución geográfica que determinan la estructura de la comunidad de elasmobranquios de las Islas Baleares (Mar Mediterráneo), utilizando datos obtenidos entre los años 2001 y 2009. Los patrones de zonación de la comunidad se analizaron mediante análisis multidimensional de escala no métrico (MDS). La variación espacio-temporal de los descriptores de la comunidad de elasmobranquios (abundancia, biomasa, peso promedio, número de las especies y diversidad), y la abundancia y la talla media de cuatro especies (S. canicula, G. melastomus, $R$. clavata, $R$. miraletus) se analizaron mediante modelos generales aditivos (GAMs). La profundidad fue el factor más importante que determinó la composición de la comunidad y el análisis MDS identificó cuatro grupos principales de especies con un $60 \%$ de similitud, que se relacionaron con la plataforma continental, el final de la plataforma, el talud superior y el talud medio. Mediante los análisis GAM se identificaron los patrones de distribución espacial con independencia de la distribución batimétrica preferente. Aunque la profundidad fue la variable dominante en todos los análisis considerados, la variabilidad geográfica en la abundancia total de elasmobranquios también fue significativa. Los resultados demuestran una reducción de la talla media de las especies de elasmobranquios en las zonas con mayor intensidad de pesca. 


\begin{abstract}
Este estudio indica la existencia de una segregación ontogénica de las principales especies ya que las variaciones geográficas y batimétricas fueron dependientes de la talla, con claras diferencias entre la distribución batimétrica de los juveniles y los adultos, pero sin un solapamiento espacial obvio. Este estudio aporta nueva información sobre la distribución espacial de las especies de elasmobranquios en las Islas Baleares, mejora el conocimiento que se requiere actualmente para la protección de los organismos y hábitats marinos, y promueve la gestión basada en el ecosistema.
\end{abstract}

Palabras clave: Elasmobranquios, Islas Baleares, MDS, GAM, descriptores de la comunidad, distribución de las especies, patrones batimétricos, segregación espacial, impacto pesquero.

\section{INTRODUCTION}

The ecological importance of elasmobranchs is becoming increasingly clear (Stevens et al., 2000; Bascompte et al., 2005). Most elasmobranchs are predators at or near the top of marine food chains; thus, their removal affects the structure and function of marine ecosystems. These effects result in changes at species level in both abundance and size structure, which can lead to changes in the trophic interactions at the community level due to selective removal of predator or prey species, removal of competitors and species replacement (Stevens et al., 2000). As a result, understanding the ecological role, biology, distribution, and life histories of elasmobranchs is an important first step towards the preservation of marine biodiversity and ecosystem functioning. At a global scale, there is current concern over the effects of increased fishing intensity on the status of the elasmobranch populations (Stevens et al., 2000). Their low recovery rates are due to sensitive life-history stages (Cailliet et al., 2005), late maturity and low fecundity, which make elasmobranchs highly vulnerable to overexploitation (Stevens et al., 2000). This is of particular concern in the highly exploited Mediterranean, where sharks and rays make up a significant proportion of the by-catch (Carbonell et al., 2003) and are targeted at various bathymetric ranges, which has led to their drastic decline in this area over the last two centuries (Ferretti et al., 2008). Protecting these fish requires detailed information about their distribution and biology; however, this information is not available for many Mediterranean species and regions.

Knowledge on the spatiotemporal variation in species distribution and habitat requirements is essential in order to implement the ecosystem based management approach to fisheries, as well as to carry out long-term monitoring programs and ad hoc studies (e.g. Gaertner et al., 2005; Ciannelli et al., 2008; Moranta et al., 2008b; Ordines et al., 2009). However, further indepth studies are required in order to gain more insight into several harvested species in a community context. Previous studies suggested that elasmobranch species in the area of the Balearic Islands are segregated in relation to trophic resources and space (Moranta et al., 2008a), although this has never been thoroughly investigated. The present study focused on understanding the spatial distribution in relation to biological, environmental and anthropogenic factors in the areas along the continental shelf and slope off the coast of the Balearic Islands. Our study aimed to describe the depth related trends and the geographic patterns shaping the elasmobranch community and the distributions of the most abundant species. To do so, we analysed elasmobranch community descriptors and species-specific information. The specific objectives of this study were: (i) to establish whether there is a spatial pattern (referring to bathymetric and geographic differences in community descriptors) in the elasmobranch community, and (ii) to investigate the effect of fishing exploitation on the spatial variability of species-specific indicators (i.e. abundance and mean length).

\section{MATERIALS AND METHODS}

\section{Study area}

There are large geographical barriers separating the Balearic Islands from the mainland (Fig. 1). The depth between the islands and the mainland ranges between $800 \mathrm{~m}$ and $2000 \mathrm{~m}$ and the minimum distance to the mainland is $90 \mathrm{~km}$. The continental shelf around Mallorca and Menorca is narrow and is characterised by rocky coasts and the absence of submarine canyons (Massutí and Reñones, 2005). Its morphology is mainly conditioned by emergent geological structures rather than by the input of sediment from the continental shelf. The bottom of the continental shelf is covered with gravel and coarse sand, with the exceptions of north and south Mallorca, where muddy sediment is present in certain bays and on the slope. In these areas, the channels between Mallorca and Menorca, which have a maximum depth of $100 \mathrm{~m}$, broaden the continental shelf. Sediments are mainly of biogenic origin as there is no river runoff, which reduces the presence of mobile sediments (Canals and Ballesteros, 1997).

The area of Menorca and the northeast coast of Mallorca are less exploited by fisheries than the south and northwest coast of Mallorca, which is characterised by a larger trawl fishery, both in terms of the number of boats and their size (Moranta et al., 2008b; Ordines and Massutí, 2009).

\section{Sampling}

This study was carried out within the framework of the Mediterranean International Trawl Surveys Programme and includes the "MEDITS" and "MIGJORN" surveys (Bertrand et al., 2002). The study analyses 577 "MEDITS" and 70 "MIGJORN" hauls, totalling 647 hauls performed during ten (from 2001 to 2009) bottom 


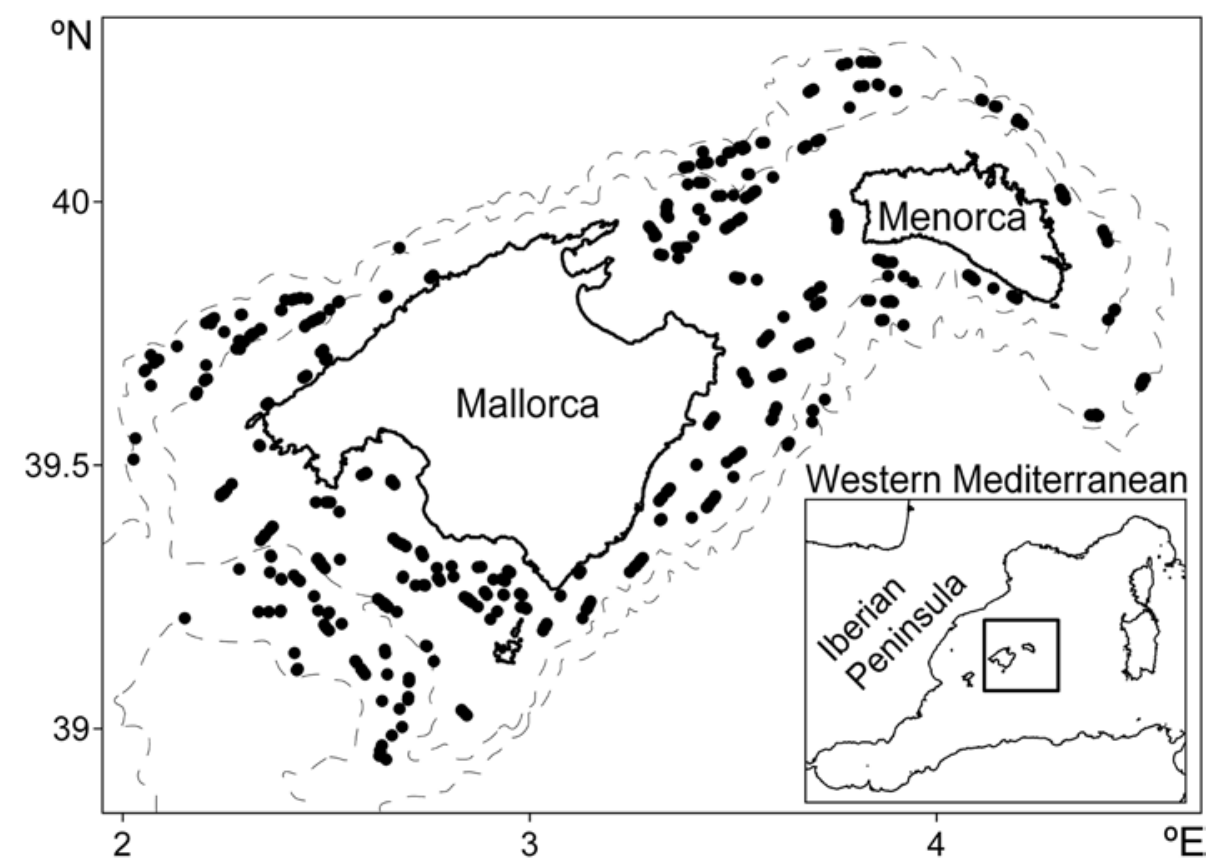

FIG. 1. - Maps of the studied area off Mallorca and Menorca Islands (Balearic Islands, western Mediterranean). Black dots represent the locations of the samples collected during the MEDITS and MIGJORN cruises, the contours around the islands represent depths of $200 \mathrm{~m}$ and $800 \mathrm{~m}$ respectively.

trawl fishing surveys at depths of 36 to $755 \mathrm{~m}$ around the continental shelf and the upper slope of Mallorca and Menorca (Balearic Islands) in the western Mediterranean (Fig. 1). The surveys were conducted on board the R/V Francisco de Paula Navarro and the R/V Cornide de Saavedra. The surveys were based on a stratified random sampling design and the sampling gear used was the GOC73, which has been commonly used in bottom trawl surveys throughout the Mediterranean since 1994 (Bertrand et al., 2002, Abelló et al., 2002).

The effective trawling time ranged from 20 to 60 min depending on the depth ( $20 \mathrm{~min}$ at $<100 \mathrm{~m}, 30 \mathrm{~min}$ between 100 and $200 \mathrm{~m}$ and $60 \mathrm{~min}$ at $>200 \mathrm{~m}$ ) with an average towing speed of 3 knots. The arrival and departure of the net to the bottom, as well as the horizontal and vertical openings of the net (16.4 and 2.8 $\mathrm{m}$ respectively), were measured using a SCANMAR system. This swept area information was used to standardise the catch (abundance and biomass). For each trawl, the individual fish species were classified by total number, size, sex (in the case of elasmobranchs) and weight. Further information on the sampling design and on the characteristics of the gear is available in Bertrand et al. (2002).

\section{Spatial analysis}

Analyses of abundance and biomass matrices of species composition were performed by means of the PRIMER 6.0 analytical software (Clarke and Gorley, 2001). Hauls containing a single species as well as those species recorded in less than $5 \%$ of the samples were not included. The Bray-Curtis index was selected as the similarity coefficient (Clifford and Stephenson, 1975). Different assemblages were identified using non-metric Multi-Dimensional Scaling (MDS).

Generalized additive modelling (GAM) (Hastie and Tibshirani, 1990) was used to fit spatial estimates of community descriptors ( $B$, biomass; $A$, abundance; $N S$, number of species; $H$, diversity - calculated using the Shannon-Wiener Index; $M W$, mean weight) and abundance and mean length of the main elasmobranch species. GAMs are non-parametric regressions with the main advantage of not requiring a priori specification of underlying functional forms between dependent and independent variables. Our objective using this technique was to detect the spatial pattern once the effect of depth had been taken out. To model the community descriptors our additive formulation was:

$$
G D_{t,(x, y)}=a_{t}+s(\lambda, \varphi)_{t}+g\left[D_{t,(\lambda, \varphi)}\right]+\varepsilon_{t,(\lambda, \varphi)}
$$

where $G D$ is the general descriptor (B, A, NS, H and MW; log-scale if the response variable was not normally distributed) at longitude $\lambda$ and latitude $\varphi$ at time $t$ (year), $a_{t}$ is a year-specific constant, $s$ is a two-dimensional non-parametric smoothing function describing the geographic effect (thin plate regression spline, Wood, 2000), with a maximum of 27 degrees of freedom [ 28 knots]), $g$ is a one-dimensional nonparametric smoothing function (cubic spline, Wood, 2000 , with a maximum of 3 degrees of freedom [4 knots]), $D$ is depth (m) and $\varepsilon$ is a normally distributed error term.

In order to model the abundance and the mean length of the main species (S. canicula, G. melastomus, 
$R$. clavata and $R$. miraletus) we used a similar model. Since we aimed to assess the main bathymetric and geographic pattern, we did not account for the interannual variation which could depend on internal demographic processes and the population dynamics. The species-specific formulation was:

$$
S P_{t,(x, y)}=\beta_{t}+s(\lambda, \varphi)_{t}+g\left[D_{t,(\lambda, \varphi)}\right]+\varepsilon_{t,(\lambda, \varphi)}
$$

where SP in this case is the species-specific descriptor ( $A$, abundance and $M L$, mean length; both log-scale if the response variable was not normally distributed) and $\beta$ the intercept. Finally, to model species-specific abundance we also included zero data; thus, the data showed a zero-inflated distribution. To tackle this data distribution, we used a model approach to analyse zero-inflated spatiotemporal data (Liu and Chan, 2010). This approach assumes that the response follows a distribution from the zero-inflated 1-parameter exponential family, with the further assumption that the probability of zero inflation is a monotone function of the mean response function (Liu and Chan, 2010). This technique bypasses the problems for analysing zero-inflated data that either focus only on the non-zero data or model the presence-absence data and the non-zero data separately (Liu and Chan, 2010; Liu et al., 2010). More details of this methodology are available in Liu and Chan (2010), which describes the R library used (COZIGAM, COnstrained ZeroInflated Generalized Additive Model). The model selection criterion (MSC) was based on the minimisa- tion of logarithmic marginal likelihoods and generalized cross validation for COZIGAM (Liu and Chan, 2010) and regular GAM (Wood, 2000). MSC values indicate the best model compromise between model complexity and fit to the observed data.

Regular GAMs for modelling the GD of the community and the ML of the four species analysed were performed using the R library $m g c v$ (Wood, 2006). All the models, calculations and data pre-processing were coded in $\mathrm{R}$ (version 2.7.1; $\mathrm{R}$ development core team, 2007).

\section{RESULTS}

\section{Species assemblages}

During the surveys, a total of 51753 specimens (ca 7.8 tons of biomass) belonging to 27 chondrichthyan species and 8 families was collected (Table 1).

The MDS analysis for the samples taken below 50 m depth identified 4 main groups with $60 \%$ similarity. These included sample assemblages grouped at the following depth intervals: $55-185 \mathrm{~m}, 190-290 \mathrm{~m}, 330-460$ $\mathrm{m}$ and $>500 \mathrm{~m}$ (Fig. 2).

The results of the SIMPER analysis identified the relative importance of several elasmobranch species corresponding to different bathymetric assemblages (Table 2).

In shallow waters, at depths between 55 and 185 m, Scyliorhinus canicula and Raja miraletus were the most important species in terms of frequency of occur-

TABLE 1. - Species caught off the Balearic Islands (western Mediterranean) between depths of $36 \mathrm{~m}$ and $755 \mathrm{~m}$. Total abundance (A: number of specimens) and biomass (B: $\mathrm{kg}$ ), frequency of occurrence $(\mathrm{F})$, depth range (D: $\mathrm{m})$ and size range $(\mathrm{S}$ : mm) are shown by species for each surveyed area.

\begin{tabular}{|c|c|c|c|c|c|c|}
\hline Family & Species & A & B & $\mathrm{F}$ & $\mathrm{D}(\mathrm{m})$ & $\mathrm{S}(\mathrm{mm})$ \\
\hline \multirow[t]{3}{*}{ Scyliorhinidae } & Galeus melastomus & 20042 & 1122 & 25 & $58-755$ & $70-700$ \\
\hline & Scyliorhinus canicula & 26615 & 2770 & 73 & $38-626$ & $90-530$ \\
\hline & Scyliorhinus stellaris & 5 & 0.74 & 0 & $60-62$ & $180-470$ \\
\hline \multirow[t]{3}{*}{ Squalidae } & Dalatias licha & 7 & 10.53 & 1 & $590-696$ & $380-940$ \\
\hline & Etmopterus spinax & 367 & 46.07 & 12 & $362-755$ & $90-500$ \\
\hline & Squalus blainvillei & 718 & 753.05 & 3 & $47-667$ & $370-790$ \\
\hline \multirow[t]{13}{*}{ Rajidae } & Dipturus oxyrinchus & 283 & 196.11 & 9 & $160-699$ & $150-1260$ \\
\hline & Leucoraja circularis & 10 & 16.09 & 1 & $252-650$ & $310-850$ \\
\hline & Leucoraja fullonica & 2 & 1.73 & 0 & 404-404 & $390-650$ \\
\hline & Rostroraja alba & 5 & 10.37 & 1 & $58-174$ & $116-530$ \\
\hline & Raja asterias & 80 & 44.40 & 5 & $50-93$ & $130-940$ \\
\hline & Raja brachyura & 39 & 7.03 & 1 & $57-399$ & $480-485$ \\
\hline & Raja clavata & 1478 & 1366.96 & 39 & $52-693$ & 63-1115 \\
\hline & Raja miraletus & 476 & 99.67 & 22 & $38-399$ & $40-440$ \\
\hline & Raja montagui & 169 & 80.31 & 11 & $36-357$ & $120-990$ \\
\hline & Leucoraja naevus & 336 & 155.91 & 17 & $47-755$ & $120-585$ \\
\hline & Raja polystigma & 274 & 73.22 & 17 & $44-749$ & $30-885$ \\
\hline & Raja radula & 343 & 205.43 & 12 & $36-172$ & $100-560$ \\
\hline & Raja undulata & 51 & 28.08 & 3 & $36-74$ & $230-600$ \\
\hline \multirow[t]{2}{*}{ Dasyatidae } & Dasyatis centroura & 2 & 254.40 & 0 & $58-59$ & $1265-3420$ \\
\hline & Dasyatis pastinaca & 91 & 107.44 & 4 & $36-77$ & 240-980 \\
\hline Chimaeridae & Chimaera monstrosa & 13 & 0.78 & 1 & $440-654$ & $50-125$ \\
\hline Centrophoridae & Centrophorus granulosus & 7 & 28.45 & 1 & $654-753$ & $870-1030$ \\
\hline \multirow[t]{2}{*}{ Triakidae } & Mustelus asterias & 2 & 1.20 & 0 & $103-107$ & $380-380$ \\
\hline & Mustelus mustelus & 22 & 31.03 & 2 & $42-141$ & $470-1400$ \\
\hline Myliobatidae & Myliobatis aquila & 288 & 370.01 & 8 & $36-98$ & $65-1950$ \\
\hline Torpedinidae & Torpedo marmorata & 26 & 8.61 & 4 & $36-368$ & $130-430$ \\
\hline
\end{tabular}




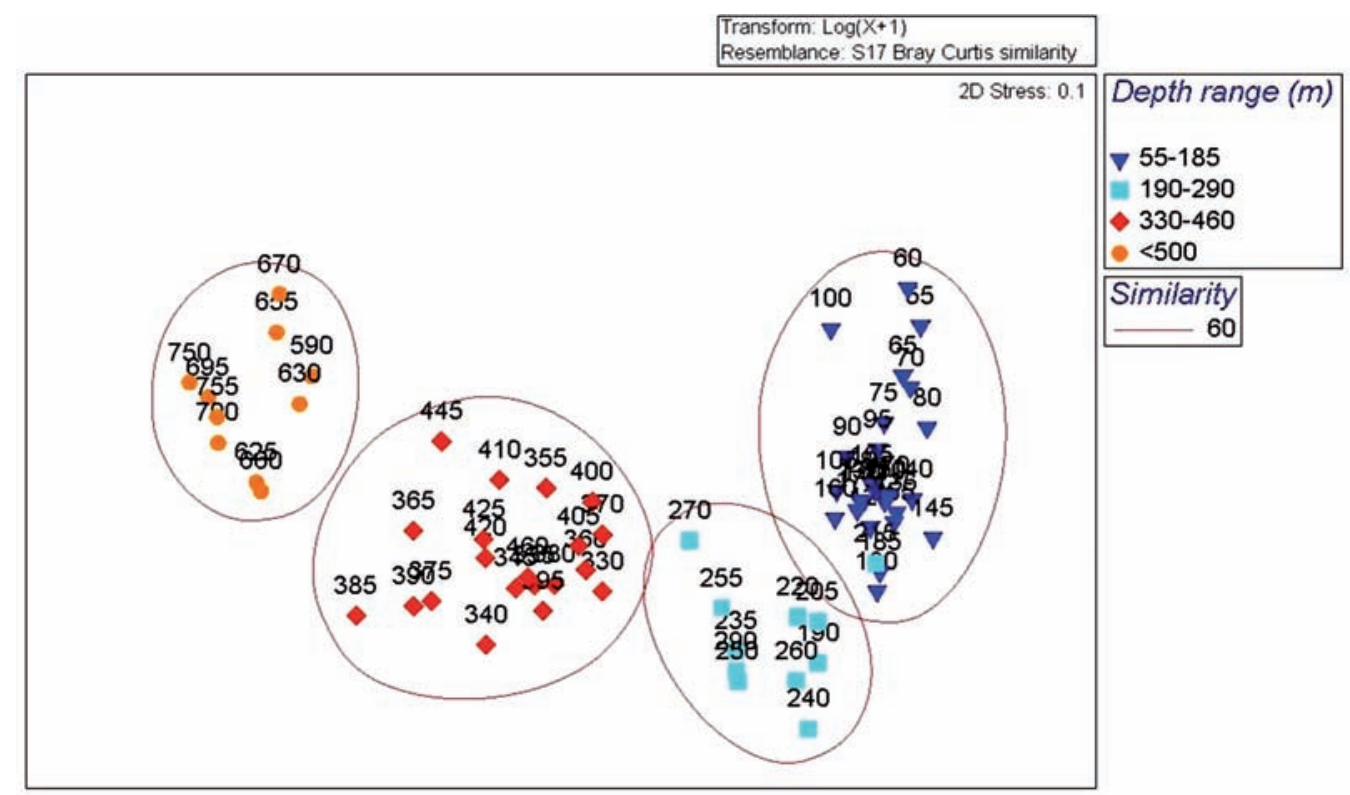

FIG. 2. - MDS ordination indicating the groupings with $60 \%$ similarity in different depth ranges, acquired through cluster analysis of elasmobranch samples obtained during MEDITS and MIGJORN trawl surveys.

TABLE 2. - The top 5 ranking species for each depth interval by abundance identified by SIMPER analysis (the abundance is expressed as a percentage of the total catch $(\%)$ for each bathymetric range and frequency of occurrence (f) as the number of samples in which the species was caught in relation to the number of samples taken at each depth stratum).

\begin{tabular}{llrr}
\hline Depth $(\mathrm{m})$ & Species & Abundance & $\mathrm{f}$ \\
\hline 55-185 & Scyliorhinus canicula & 33.0 & 100.0 \\
& Raja miraletus & 14.2 & 100.0 \\
& Raja radula & 9.6 & 75.0 \\
& Raja clavata & 9.52 & 91.7 \\
& Raja polystigma & 9.0 & 91.7 \\
190-290 & Scyliorhinus canicula & 28.6 & 83.3 \\
& Raja clavata & 25.9 & 83.3 \\
& Leucoraja naevus & 15.3 & 83.3 \\
& Raja montagui & 6.6 & 66.7 \\
& Raja polystigma & 6.2 & 75.0 \\
330-460 & Dipturus oxyrinchus & 31.2 & 83.3 \\
& Galeus melastomus & 22.3 & 83.3 \\
& Raja clavata & 19.5 & 83.3 \\
& Scyliorhinus canicula & 11.2 & 83.3 \\
& Squalus blainvillei & 2.3 & 33.3 \\
& Galeus melastomus & 46.2 & 83.3 \\
& Etmopterus spinax & 38.5 & 83.3 \\
& Dalatias licha & 3.6 & 58.3 \\
& Centrophorus granulosus & 2.6 & 33.3 \\
& Dipturus oxyrinchus & 2.6 & 41.7 \\
& Chimaera monstrosa & 2.1 & 33.3 \\
\hline
\end{tabular}

rence. In the depth range between 190 and $290 \mathrm{~m}, S$. canicula remained important, but was closely followed by Raja clavata in terms of abundance and frequency of occurrence. The depth range between 330 and 460 m was dominated by Dipturus oxyrinchus and Galeus melastomus, which made up $31 \%$ and $22 \%$ respectively of the total catch abundance. Finally, the samples taken deeper than $500 \mathrm{~m}$ were dominated by the sharks G. melastomus and Etmopterus spinax, which made up $46 \%$ and $38 \%$ respectively of the total catch abundance.
TABLE 3. - Results of the generalized additive model for the community descriptors analysed ( $A$, abundance; $B$, biomass; $N S$, number of species; $H$, diversity; $M W$, mean weight). Note that the selection criteria are not shown because the most complete model including both bathymetric, $s($ depth), and geographic, $s(\lambda, \varphi)$, terms was always the most parsimonious. For each model the intercept is year-specific and is shown in Figure 3. Asterisks denote significance levels: ***, $\mathrm{p}<0.001 ; * *, \mathrm{p}<0.01 ; *, \mathrm{p}<0.05$. DE refers to the percentage of variance explained.

\begin{tabular}{lccc}
\hline Model & $\mathrm{s}($ depth $)$ & $\mathrm{s}(\lambda, \varphi)$ & $\mathrm{DE}(\%)$ \\
\hline $\mathrm{A}$ & $2.97 * * *$ & $21.35^{* * *}$ & 37.8 \\
$\mathrm{~B}$ & $2.69 * * *$ & $30.77^{* * *}$ & 41.4 \\
$\mathrm{NS}$ & $3 * * *$ & $21.94^{* * *}$ & 25.6 \\
H & $2.99 * *$ & $20.51^{* * *}$ & 19.3 \\
MW & $2.52^{* * *}$ & $22.16^{* * *}$ & 48.3 \\
\hline
\end{tabular}

\section{Spatiotemporal variability of the community descriptors}

Data collected during 8 years, coming from 10 bottom trawl fishing surveys totalling 605 hauls, were included in the GAM models. Table 3 summarises the best model for each community descriptor.

In all cases, inter-annual variability (temporal factor) and bathymetric and geographic effect (smoothing terms) had a significant effect on the spatial distribution of the community descriptors. The percentages of deviance explained by the models ranged from 19.3\% for diversity to $48.3 \%$ for mean weight. Figure 3 shows the inter-annual variability and the functional form of the temporal factor and smoothing terms.

The abundance and biomass (Fig. 3a, b) showed similar temporal patterns, and the average values of 2002 and 2007 were higher in comparison to other years. The bathymetric distribution showed different maxima at $200 \mathrm{~m}$ and $300 \mathrm{~m}$ for biomass and abundance respectively. The remaining variance explained 
a)

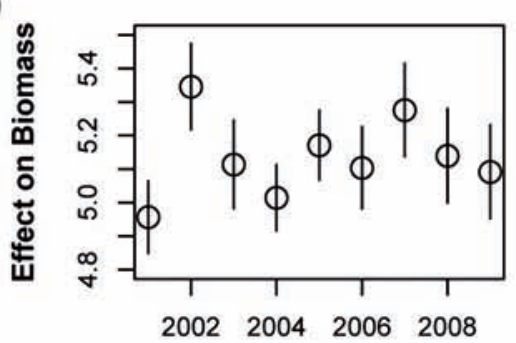

b)

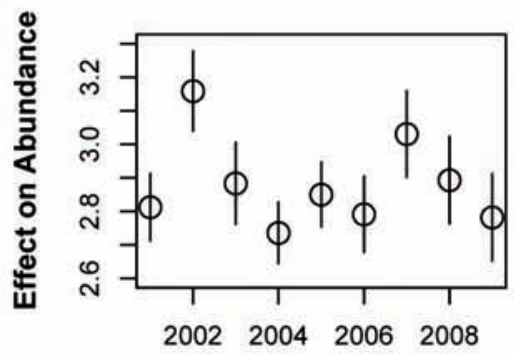

c)

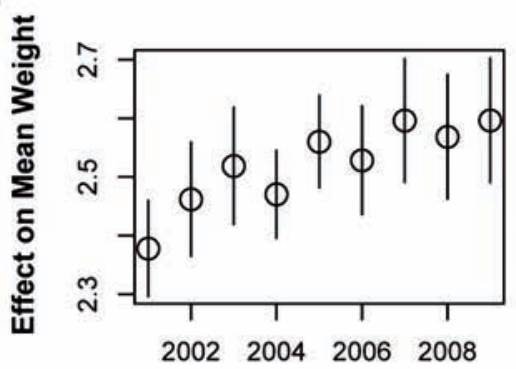

d)

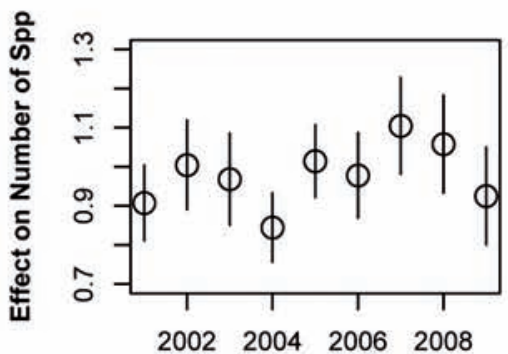

e)

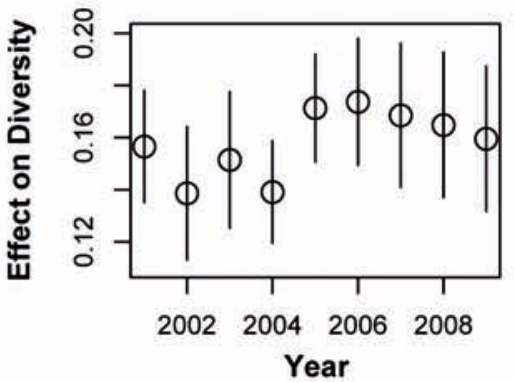

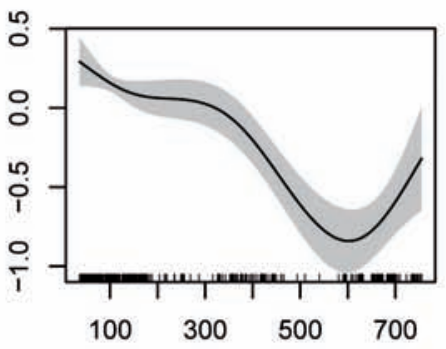
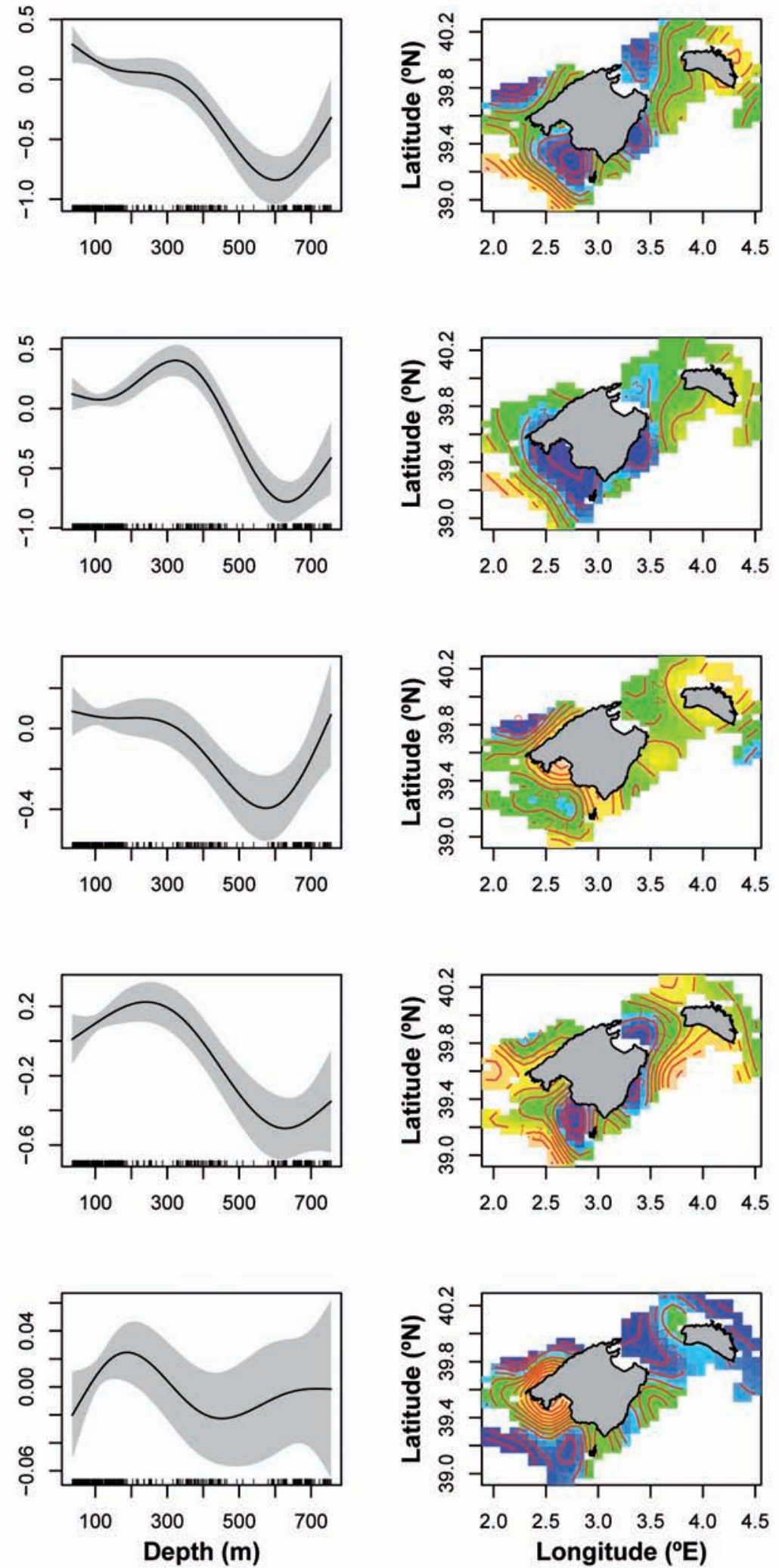

FIG. 3. - Partial effects of year (left column), bottom depth (middle column), and position (right column) on elasmobranch community abundance (a), biomass (b), mean fish weight (c), number of species (d) and diversity (e) estimated from the spatially explicit generalized additive model. For the position plots, orange indicates high predicted values, green medium values and blue indicates low values. Shaded areas on the bottom depth plots and lines going through the dots on the year plots are $95 \%$ confidence intervals, and tick marks on the $x$-axes of the depth plots indicate sampling intensity. 
TABLE 4. - Model selection for the generalized additive model of abundance and mean length of the four species studied. Estimated intercepts $(\beta)$ and estimated degrees of freedom for the two nonparametric terms are shown. The base model denotes the complete model including both bathymetric, $\mathrm{s}(\mathrm{depth})$, and geographic, $\mathrm{s}(\lambda, \varphi)$, terms. Asterisks denote significance levels: $* * *: \mathrm{p}<0.001 ; * *: \mathrm{p}<0.01 ; *: \mathrm{p}<0.05$ and $\mathrm{ns}$ : not significant or $\mathrm{p} \geq 0.1$. Note that the model selection criterion (M.S.C.) applied for the abundance models (COZIGAM) was the logarithmic marginal likelihood, while GCV (Generalized Cross Validation) was applied for regular GAMs. Figures showing the most parsimonious models are indicated. DE refers to the percentage of variance explained by regular GAMs (i.e. mean length); note that DE is not shown for abundance analyses due to the methodological constraints of COZIGAM (see Liu and Chan, 2010 for details). Note that the G. melastomus mean length intercept was considerably lower compared to the other mean length analyses due to the log-transformation prior to the analyses.

\begin{tabular}{|c|c|c|c|c|c|c|c|}
\hline Species & Model & $\beta$ & s(depth) & $s(\lambda, \varphi)$ & M.S.C & Figure & $\mathrm{DE}(\%)$ \\
\hline \multicolumn{8}{|l|}{ Abundance } \\
\hline \multirow[t]{3}{*}{ G. melastomus } & base & $6.47 * * *$ & $4.29 * *$ & ns & -402.512 & \multirow{3}{*}{ Fig. $5 \mathrm{~A}$} & - \\
\hline & base-s $(\lambda, \varphi)$ & $6.46^{* * *}$ & $4.68 * *$ & - & -398.882 & & - \\
\hline & base- s(depth) & $6.02 * * *$ & - & $20.93 * *$ & -406.149 & & - \\
\hline \multirow[t]{3}{*}{ S. canicula } & base & $6.42 * * *$ & $4.53 * * *$ & $21.43 * * *$ & -764.806 & \multirow[t]{3}{*}{ Fig. 5B } & - \\
\hline & base-s $(\lambda, \varphi)$ & $6.40 * * *$ & ns & - & -810.878 & & - \\
\hline & base-s(depth) & $6.39 * * *$ & - & $22.13 * * *$ & -803.878 & & - \\
\hline \multirow[t]{3}{*}{ R. clavata } & base & $14.15 * * *$ & $1.74 * * *$ & $18.26^{* * * *}$ & -775.928 & \multirow[t]{3}{*}{ Fig. 5C } & - \\
\hline & base-s $(\lambda, \varphi)$ & $14.23 * * *$ & $2.36^{* *}$ & - & -790.216 & & - \\
\hline & base-s(depth) & $14.12 * * *$ & - & ns & -803.361 & & - \\
\hline \multirow[t]{3}{*}{ R. miraletus } & base & $4.31 * * *$ & $3.23 * *$ & ns & -382.724 & \multirow{3}{*}{ Fig. 5D } & - \\
\hline & base-s $(\lambda, \varphi)$ & $4.07 * * *$ & $3.11^{*}$ & & -366.562 & & - \\
\hline & base-s(depth) & $4.39 * * *$ & - & 16.32 & -388.794 & & - \\
\hline \multicolumn{8}{|l|}{ Mean length } \\
\hline \multirow[t]{3}{*}{ G. melastomus } & base & $5.54 * * *$ & $1.12 * * *$ & $21.09 * * *$ & 0.106 & \multirow[t]{3}{*}{ Fig. 6A } & 45.7 \\
\hline & base-s $(\lambda, \varphi)$ & $5.54 * * *$ & $1 * * *$ & - & 0.124 & & 26.6 \\
\hline & base-s(depth) & $5.54 * * *$ & - & $25.55 * * *$ & 0.127 & & 34.4 \\
\hline \multirow[t]{3}{*}{ S. canicula } & base & $343.17 * * *$ & $4.86 * * *$ & $24.56 * * *$ & 2924 & \multirow[t]{3}{*}{ Fig. 6B } & 59.8 \\
\hline & base-s $(\lambda, \varphi)$ & $343.17 * * *$ & $3.93 * * * *$ & - & 4227 & & 40.5 \\
\hline & base-s(depth) & $343.17 * * *$ & - & $24.56 * * *$ & 3479 & & 52.2 \\
\hline \multirow[t]{3}{*}{ R. clavata } & base & $506.56 * * *$ & $2.66 * * *$ & $15.76 * *$ & 20457 & \multirow[t]{3}{*}{ Fig. $6 \mathrm{C}$} & 27.5 \\
\hline & base-s $(\lambda, \varphi)$ & $506.56 * * *$ & $2.48 * * *$ & - & 21206 & & 18.3 \\
\hline & base-s(depth) & $506.56 * * *$ & - & $19.12 * * *$ & 23800 & & 16 \\
\hline \multirow[t]{3}{*}{ R. miraletus } & base & $328.69 * * *$ & $1 * * *$ & $14.93 * * *$ & 3140 & \multirow[t]{3}{*}{ Fig. 6D } & 35.3 \\
\hline & base-s $(\lambda, \varphi)$ & $328.69^{* * *}$ & $1 * * *$ & - & 3510 & & 18.9 \\
\hline & base-s(depth) & $328.69 * * *$ & - & $17.86 * * *$ & 3707 & & 24.9 \\
\hline
\end{tabular}

by the geographic effect showed both higher abundance and biomass around Menorca and decreased abundance around Mallorca with the lowest values on the continental shelf southwest of Mallorca. Mean fish weight (Fig. 3c) showed a general increase during the first five years, then a slight decrease in the following years. The effect of depth on mean fish weight decreased down to $400 \mathrm{~m}$, and then increased. The variance of mean fish weight explained by the geographic effect was generally larger in the area around Mallorca.

Both the interannual variability and bathymetric effect showed consistent results for the number of species and diversity (Fig. 3d, e), with an increase in recent years and greater values in shallow waters with peaks around $200 \mathrm{~m}$. However, the variance left by the other covariates and explained by the spatial effect showed more species in the area around Menorca, while the diversity was higher on the shelf southwest of Mallorca and lower around Menorca.

\section{Geographical and bathymetric effect on individual species}

GAMs were also used to analyse data on the four main species in terms of abundance and frequency of occurrence: S. canicula, R. clavata, R. miraletus and $G$. melastomus (Table 1). Table 4 shows a summary of the results of the best models for abundance (Fig. 4) and mean length (Fig. 5) for the selected species.

Our results show the effect of depth on the spatial pattern of the two species-specific indicators (Table 4 and Figs. 4 and 5). Once the bathymetric effect had been accounted for, a geographic pattern for abundance was only observed in two species: $S$. canicula and $R$. clavata. Only depth significantly affected the abundance of G. melastomus (Fig. 4a) and R. miraletus (Fig. $4 \mathrm{~b}$ ), and consequently their spatial distribution was exclusively depth-dependent. The highest abundance found for G. melastomus was between 300 and $400 \mathrm{~m}$. In contrast, $R$. miraletus occupied shallow waters with a maximum around $75 \mathrm{~m}$. Both the geographic variability and the depth significantly affected the abundance of S. canicula (Fig. 4c) and R. clavata (Fig. 4d). The maximum abundance of $S$. canicula was found between 200 and $300 \mathrm{~m}$, with a lower abundance around Mallorca compared to Menorca. R. clavata showed the highest abundance around a depth of $200 \mathrm{~m}$ in two areas: the shelf west of Mallorca and the area northeast of Menorca. The lowest abundance was in the Menorca channel.

The mean length analysis showed consistent and complementary results to those obtained by the species abundance analysis. In contrast to the abundance analysis, the best models always contained both bathymetric and geographic effects (Table 4). Shelf distrib- 

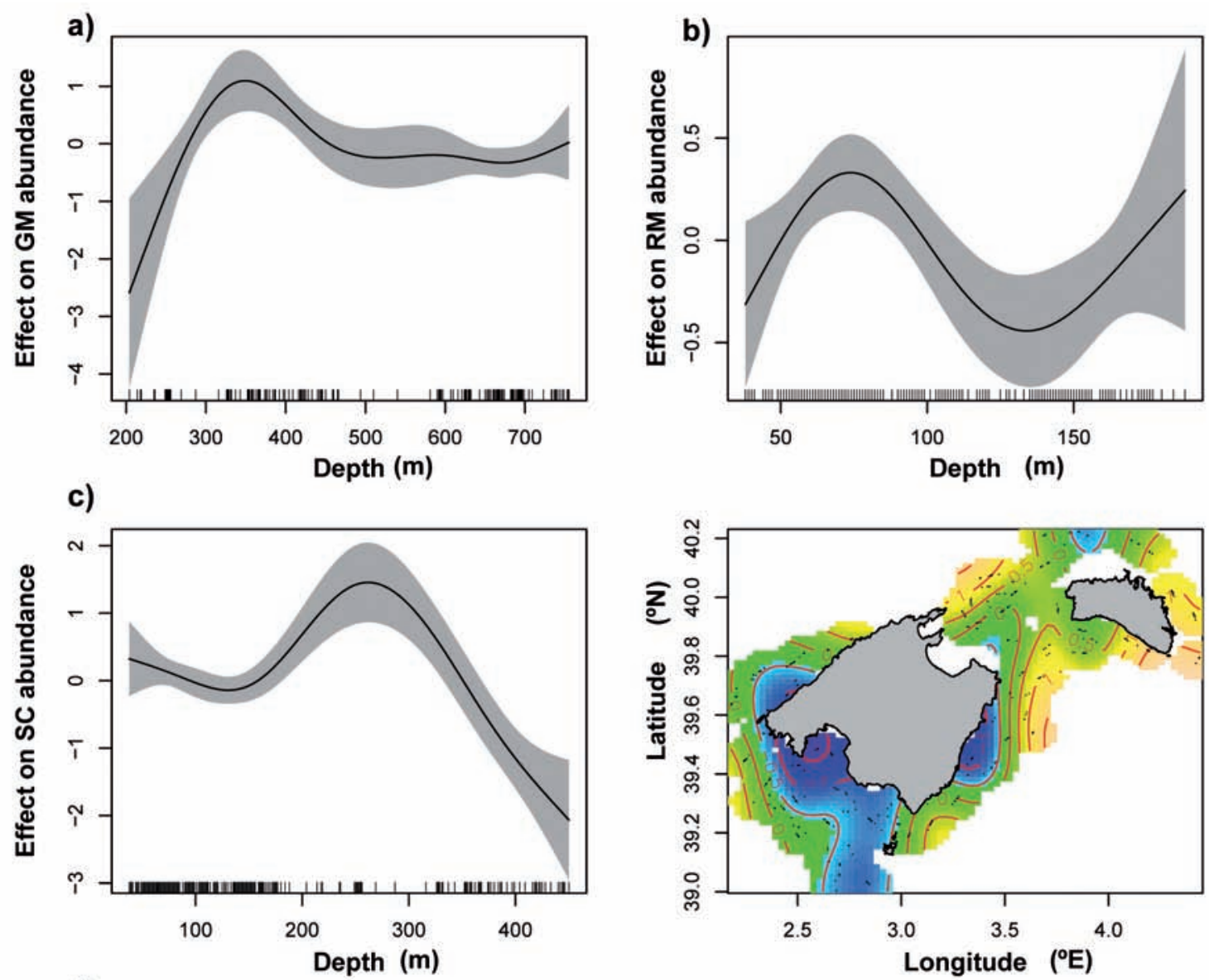

d)

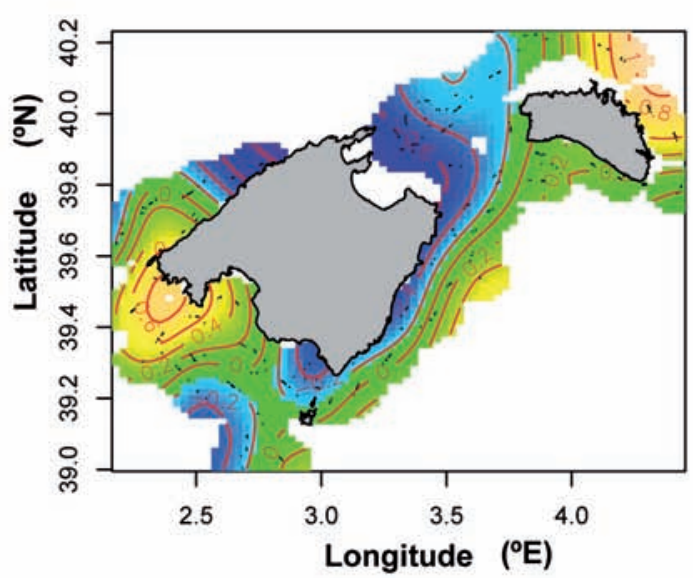

FIG. 4. - The partial effects of bottom depth and geographic position on G. melastomus (a), R. miraletus (b), S. canicula (c) and R. clavata (d) abundance, estimated from the generalized additive model. For the position plot, orange indicates high predicted values, green medium values and blue indicates low values. Shaded areas on the depth plot are 95\% confidence intervals, and tick marks on the $x$-axes of the depth plots indicate sampling intensity. Only those maps resulting from significant models were included. Note that the $x$-axes for the plots representing the bathymetric distribution are different in order to take into account the distribution ranges of the species.

uted species, S. canicula, $R$. miraletus and $R$. clavata, showed a high abundance of large individuals in shallow waters (Fig. 5b, c, d; although for S. canicula and $R$. clavata large individuals were also found deeper within their distribution range), while the slope species G. melastomus showed an opposing pattern, with large individuals in deeper waters (Fig. 5a). Some interesting features can also be identified within the geographic effect. Of special interest were the low mean length values of G. melastomus, which were only observed on the north slope of Mallorca (Fig. 5a). It is also important to note that, although $S$. canicula had a lower abundance around Mallorca compared to Menorca (Fig. 5c), the individuals off Mallorca were larger 
a)

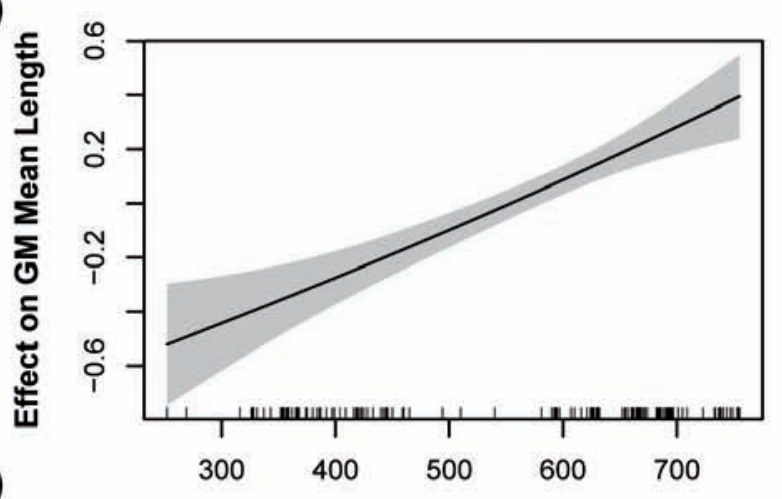

b)

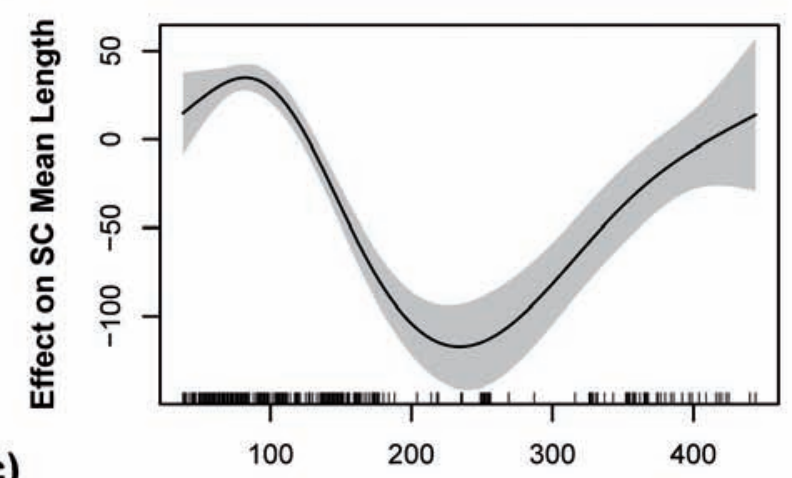

c)

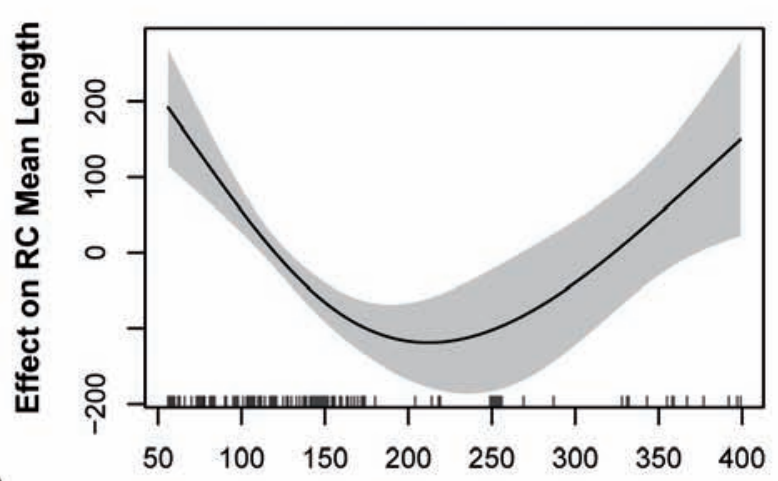

d)

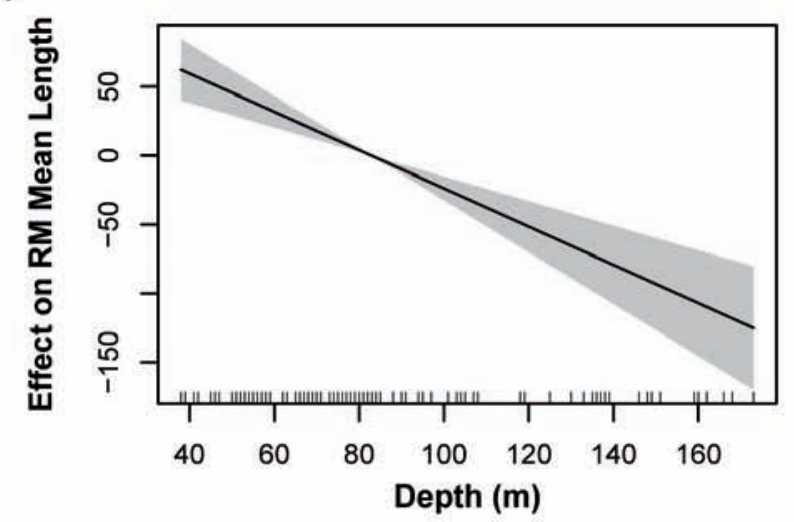

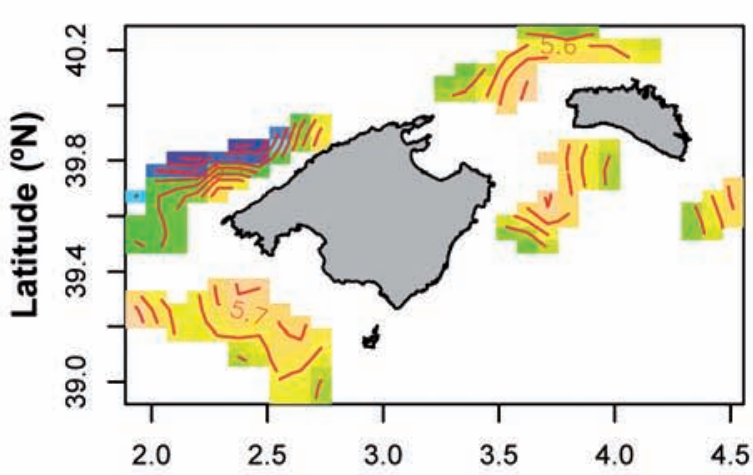
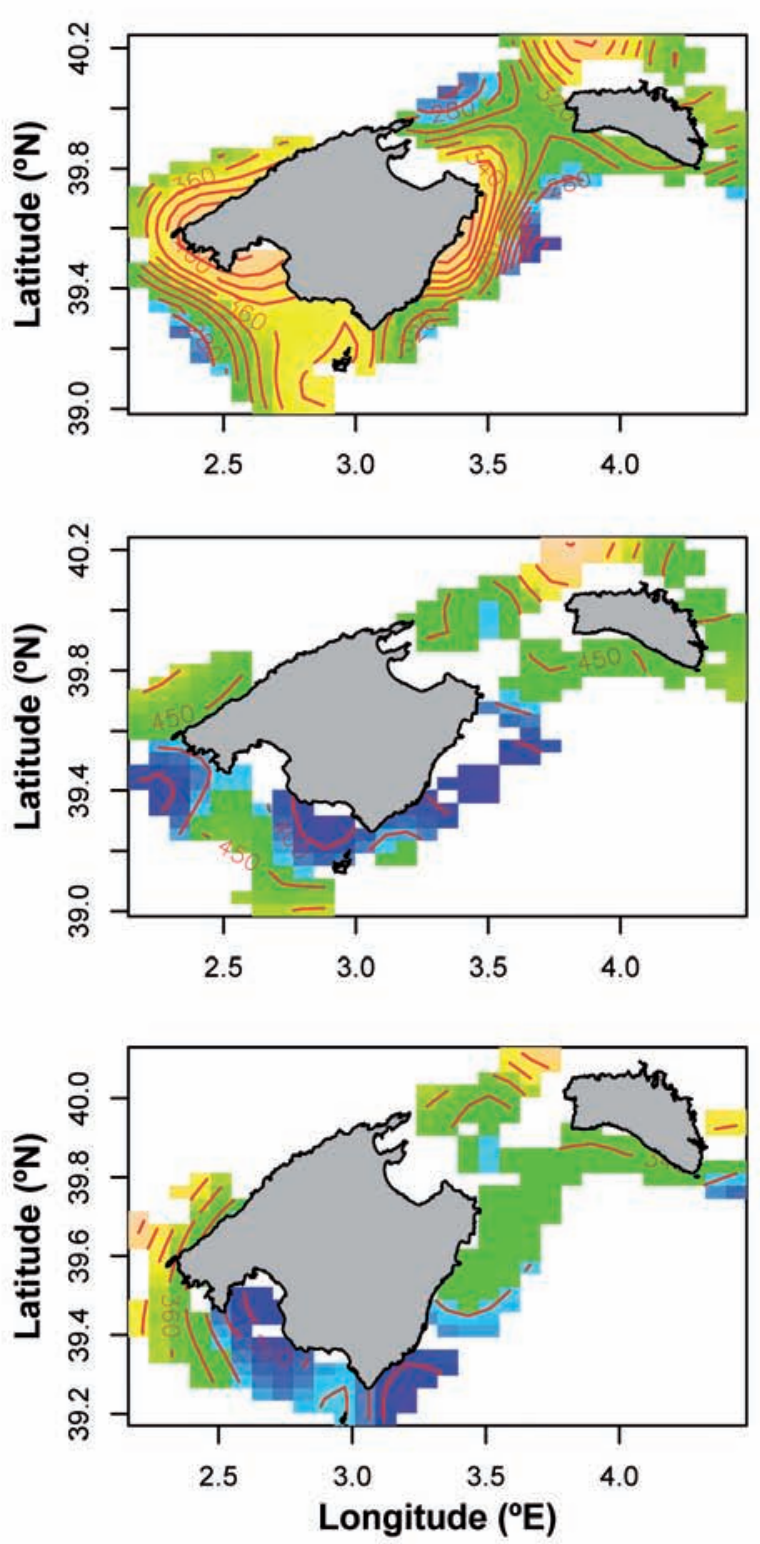

FIG. 5. - Partial effects of bottom depth and geographic position on G. melastomus (a), S. canicula (b), R. clavata (c) and R. miraletus (d) mean length, estimated from the spatially explicit variable coefficient generalized additive model. For the position plot, orange indicates high predicted values, green medium values and blue indicates low values. Shaded areas on the depth plot are 95\% confidence intervals, and tick marks on the $x$-axes of the depth plots indicate sampling intensity. Note that the $x$-axes for the plots representing the bathymetric distribution are different in order to take into account the distribution ranges of the species. 
compared to those off Menorca (Fig. 5b). Only one (shelf off Menorca) of the two areas of high abundance of $R$. clavata showed large individuals (Fig. $5 \mathrm{c}$ ). The highest numbers of large individuals of $R$. miraletus were found on the shelf west of Mallorca and the area northeast of Menorca (Fig. 5d).

\section{DISCUSSION}

The four elasmobranch assemblages detected in the present study of the Balearic Islands were found to correspond to the bathymetric regions of the surveyed area: the first assemblage had an approximate depth range of 55 to $185 \mathrm{~m}$, which corresponds to the continental shelf; the second had a depth range of 190 to 290 $\mathrm{m}$, which corresponds to the shelf break; the third had a range of 330 to $460 \mathrm{~m}$, which corresponds to the upper slope; and finally the fourth assemblage started at $500 \mathrm{~m}$ and went down to the final sampling depth (755 $\mathrm{m})$, which corresponds to the middle slope. The depth is the main factor for establishing these elasmobranch communities, which has also been reported in earlier studies in this area (Massutí and Moranta, 2003), as well as studies from other parts of the Mediterranean (Demestre et al., 2000a). Previous studies conducted off the Balearic Islands on the whole fish community revealed similar bathymetric assemblages (Moranta et al., 1998; Massutí and Reñones, 2005).

The results obtained for abundance, biomass and number of species of the elasmobranch community in relation to geographic position (i.e. bathymetry independent) clearly evidence the direct effect fishing has on these community descriptors in the studied area. For all three, the areas with low values coincided with the areas that have high fishing intensity; likewise, the areas with high values of these community descriptors in our study are closely associated with regions where fishing intensity is lower (Fig. 4a, b, d).

At species level, the bathymetric trend was evident in the distribution of the four elasmobranch species studied. In S. canicula the abundance peak at 250 $\mathrm{m}$ was most likely associated with juveniles, usually found at depths around $200 \mathrm{~m}$, while adults had a wider bathymetric distribution, and commonly occurred in the shallows (Sánchez, 1993; Sánchez et al., 2002; Rodríguez-Cabello et al., 2004). This pattern of bathymetric distribution in S. canicula was further confirmed by the results of the mean length of this species with adults (high values of mean length) mainly distributed in the shallows, and juveniles (low values of mean length) distributed around $250 \mathrm{~m}$. R. clavata showed a similar bathymetric distribution pattern to S. canicula, with adults below a depth of $100 \mathrm{~m}$, and a peak in abundance of juveniles in the depth range between 200 and $300 \mathrm{~m}$. According to this, juveniles of $R$. clavata showed a bathymetric overlap with $S$. canicula juveniles. However, once the effect of depth had been eliminated, $R$. clavata was found to be the most abundant on the shelf west off Mallorca. Thus, even though they overlap bathymetrically, the juveniles of $R$. clavata and $S$. canicula do not overlap in space. This indicates that there could be intraspecific competition for space and trophic resources, which is known to be among the most important factors influencing segregation of marine species (Haedrich, 1997; Moranta et al., 2008b). Nevertheless, other ecologically similar species in the area (e.g. other non-elasmobranch fish) could also be competing for the same resources.

The ray $R$. miraletus was found in shallower waters in comparison with the other species studied, with a bathymetric range down to $150 \mathrm{~m}$ and a peak in abundance between 50 and $100 \mathrm{~m}$. These findings are similar to those of the previous study conducted in the central Mediterranean, where R. miraletus was found between 50 and $150 \mathrm{~m}$ (Relini et al., 1999), and off Tunisia, where the distribution of this species was reported down to a depth of $200 \mathrm{~m}$ (Capapé and Quignard, 1974). The abundance peak of G. melastomus between 300 and $400 \mathrm{~m}$ was also associated with a larger number of juveniles, in this case found in the shallower part of its bathymetric range; thus, showing bathymetric overlap with juveniles of $S$. canicula. According to our results, the adults of G. melastomus were generally distributed deeper within their bathymetric range, which was also confirmed by the mean length results for this species, which clearly showed increasing values with increasing depth. The study by Tursi et al. (1993) in the Ionian Sea reports G. melastomus juveniles almost exclusively between 200 and $300 \mathrm{~m}$, whereas in the depth range between 400 and $650 \mathrm{~m}$ the population was mixed, and included juveniles, maturing individuals and adults. G. melastomus expressed a "bigger-deeper" distribution trend, with the relative size increasing with depth (Fig. 5a), unlike the other three species whose adults were mainly found in shallow waters (Fig. 5b, c, d). The possible ecological reason for the "bigger-deeper" phenomenon in G. melastomus can be assigned to the biomass peak of decapod crustaceans between $400 \mathrm{~m}$ and $700 \mathrm{~m}$ (Maynou and Cartes, 2000), which are an important part of the diet of this species (Valls et al., 2011). Crustaceans make up the majority of the diet of $R$. miraletus, $S$. canicula and $R$. clavata (Valls et al., 2011). This may originate a phenomenon of competitive exclusion due to the exploitation of similar resources, in this case in favour of G. melastomus at a depth interval between $400 \mathrm{~m}$ and $700 \mathrm{~m}$. Based on the competitive exclusion principle, other species are forced to retreat to the bathymetric and/or geographic range to which they are most highly adapted in relation to the other potential inhabitants. According to this phenomenon it is possible that a strong selection pressure for diversification in the trophic strategies of these four species is the main explanation for their geographic and bathymetric segregation. Although the reproductive cycle of the species can have different seasonal patterns (i.e. recruitment events or adult spawning aggregations) which can affect the bathymetric and geographic distribution of the 
species, it is difficult to address this issue due to the lack of seasonal surveys.

The four elasmobranch species studied also showed evidence of the direct effect of fishing on their spatial distribution and demography (i.e. mean length), which is consistent with the elasmobranch community descriptors. It is well known that fishing effort in the Balearic Islands is displaced towards greater depth (Moranta et al., 2008b; Guijarro et al., in press), and thus has different effects on the populations of the two most common sharks in the area, $S$. canicula and $G$. melastomus. In our study, S. canicula expressed the opposite spatial pattern of abundance and mean lengthlow abundance around Mallorca but with higher mean length in the same area. This suggests that there are different mortality rates for juveniles (found deeper) and adults (shallow distribution) (see above). The increase in adult populations around Mallorca could be related to the scavenging and opportunistic behaviour of this species, which has been observed to be enhanced due to the discards of fishing activity both in the Atlantic (Olaso et al., 1998) and the Mediterranean (Demestre et al., 2000b). In contrast, G. melastomus was expected to display a homogeneous depth-dependent spatial distribution. However, the smallest mean length was observed in the area northwest of Mallorca, which suggests there was a reduction in both the spatial distribution and their demography caused by the higher fishing effort in this region. Combined with the "bigger-deeper" distribution trend this species expresses, fishing in the area results in high selectivity for larger individuals. The outcome is an age/size truncation often referred to as an 'age truncation effect' (see review in Hsieh et al, 2010), which may have consequences for the population and community dynamics.

The large scale removals of certain species of predators reduces the environmental heterogeneity created by these organisms and can even impact organisms in the water column (Thrush and Dayton, 2010). For instance, the impact of declines in cod stocks and other predatory fish on the Scotian Shelf had a detrimental effect on the populations of shrimp, crabs and other benthic organisms as well as the nutrient dynamics (Frank et al., 2005). Therefore, overexploiting elasmobranchs in the area of the Balearic Islands can have a detrimental effect on the whole ecosystem by disturbing the complex equilibrium these predators provide. Our study suggests that these ecosystem alterations could be spatially heterogeneous due to clear differences in the species-specific consequences of the fishing exploitation.

The results from this study increase our knowledge of elasmobranch biology and distribution within the investigated areas. Combining the bathymetric and geographic distribution, our study shows a complete spatial segregation of the main elasmobranch species despite the apparent similarity of their diets and the geographical availability of resources. Our results also highlight that fishing is most likely heterogeneously affecting the spatial structure and dynamics of the elasmobranch community, and at the same time, the entire ecosystem due to both the depletion of the relative abundances (around Mallorca) and the demographic structure of certain species (e.g. juveniles of $S$. canicula around Mallorca, and adults of G. melastomus northwest of Mallorca). Thus, the elasmobranchs in the area of the Balearic Islands could potentially be a very valuable indicator of the fishing impact on the ecosystem, and thus monitoring future changes in the elasmobranch community should be given greater importance. With this in mind, it is important that the fishery around the Balearic Islands develops technical measures in order to protect the predatory fish populations in this area, including the elasmobranchs, which would subsequently ensure a healthy and sustainable ecosystem.

\section{ACKNOWLEDGEMENTS}

A.G. would like to thank CEES and Nils Christian Stenseth for facilitating and partially funding a short stay at his lab. A.G. received support from the Student Awards Agency for Scotland and the Instituto Español de Oceanografía (Centre Oceanogràfic de Balears). M.H. received support from Marie Curie Intra-European fellowship (IEF, FP7-PEOPLE-IEF-2008, European Commission; project No 236549).

\section{REFERENCES}

Abelló, P., J.A. Bertrand, L. Gil de Sola, C. Papaconstantinou, G. Relini and A. Souplet. - 2002. Mediterranean marine demersal resources: the MEDITS international trawl survey (1994-1999). Sci. Mar., 66(Suppl. 2): 5-280.

Bascompte, J., C.J. Melián and E. Sala. - 2005. Interaction strength combinations and the overfishing of a marine food web. Proc. Natl. Acad. Sci. USA., 102(15): 5443-5447.

Bertrand, J.A., L. Gil de Sola, C. Papaconstantinou, G. Relini and A. Souplet. -2002 . The general specifications of the MEDITS surveys. Sci. Mar., 66(2): 9-17.

Cailliet, G.M., J.A. Musick, C.A. Simpfendorfer and J.D. Stevens. - 2005. Ecology and life history characteristics of chondrichthyan fishes. In: Sharks, Rays and Chimaeras: The Status of the Chondrichthyan Fishes. Status Survey. In: S.L. Fowler, R.D. Cavanagh, M. Camhi, G.H. Burgess, G.M. Cailliet, S.V. Fordham, C.A. Simpferdorfer and J.A. Musick (eds.), Gland, Switzerland and Cambridge, UK: IUCN/SSC Shark Specialist Group. 12-18.

Canals, M. and E. Ballesteros. - 1997. Production of carbonate particles by phytobenthic communities on the Mallorca-Menorca shelf, northwestern Mediterranean Sea. Deep-Sea Res., 44: 611-629.

Capapé, C. and J.P. Quignard. - 1974. Contribution à la biologie des Rajidae des côtes tunisiennes. 1. Raja miraletus, Linné, 1758: répartition géographique et bathymétrique, sexualité, reproduction, fécondité. Arch. Inst. Pasteur Tunis, 51: 39-60

Carbonell, A., F. Alemany, P. Merella, A. Quetglas and E. Román. - 2003. The by-catch of sharks in the western Mediterranean (Balearic Islands) trawl fishery. Fish. Res., 61: 7-18.

Clarke, K.R. and R.N. Gorley. - 2001. PRIMER v5: User Manual/ Tutorial. PRIMER-E, Plymouth.

Clifford, H. and W. Stephenson. - 1975. An introduction to numerical classification. Academic Press, New York.

Ciannelli, L., P. Fauchald, K.S. Chan, V.N. Agostini and G.E. Dingsor. - 2008. Spatial fisheries ecology: Recent progress and future prospects. J. Mar. Syst., 71: 223-236.

D’Onghia, G., A. Matarrese, A. Tursi and L. Sion. - 1995. Observations on the depth distribution pattern of the small-spotted 
catshark in the North Aegean Sea. J. Fish Biol., 47: 421-426.

Demestre, M., P. Sánchez and P. Abelló. - 2000. Demersal fish assemblages and habitat characteristics on the continental shelf and upper slope of the north-western Mediterranean. J. Mar. Biol. Ass. UK, 80: 981-988.

Demestre, M., P. Sánchez and M.J. Kaiser - 2000b. The behavioural response of benthic scavengers to otter-trawling disturbance in the Mediterranean. In: M.J. Kaiser, S.J. De Groot (eds.), Effects of Fishing on Non-target Species and Habitats. Biological, Conservation and Socioeconomic Issues. Blackwell Science, Oxford, 121-129.

Ferretti, F., R.A. Myers, F. Serena and H.K. Lotze. - 2008. Loss of Large Predatory Sharks from the Mediterranean Sea. Conserv. Biol., 22: 952-964.

Frank, K.T., B. Petrie, J.S. Choi and W.C. Leggett. - 2005. Trophic cascades in a formerly cod-dominated ecosystem. Science, 308: 1621-23.

Gage, J.D. and P.A. Tyler. - 1991. Deep-Sea Biology: A Natural History of Organisms at the Deep-Sea Floor. Cambridge University Press, Cambridge, 504.

Gaertner, J.C., J.A. Bertrand, L. Sola, J. Durbec, E. Ferrandis, and A. Souplet. - 2005. Large spatial scale variation of demersal fish assemblage structure on the continental shelf of the NW Mediterranean Sea. Mar. Ecol. Prog. Ser., 297: 245-257.

Guijarro, B., E. Massutí, A. Quetglas, J. Moranta, F. Ordines, M. Valls and N. Gonzalez. - in press. An approach to the diagnosis of elasmobranch populations in the circa-littoral soft bottoms off the Balearic Islands (north-western Mediterranean). Sci. Mar.

Haedrich, R.L. - 1997. Distribution and population ecology. In: D.J. Randall and A.P. Farrell (eds.), Deep-sea fishes, pp. 79-114. Academic Press, San Diego.

Hastie, T. and R. Tibshirani. - 1990. Generalized Additive Models. Chapman and Hall, London.

Hsieh, C.H., A. Yamauchi, T. Nakazawa and W.F. Wang. - 2010. Fishing effects on age and spatial structures undermine population stability of fishes. Aquat. Sci., 72: 165-178.

Liu, H. and K.S. Chan. - 2010. Introducing COZIGAM: An R Package for Unconstrained and Constrained Zero-Inflated Generalized Additive Model Analysis. J. Stat. Softw. In press.

Liu, H., L. Ciannelli, M.B. Decker, C. Ladd and K.S. Chan. - 2010. Nonparametric threshold model of zero-inflated spatio-temporal data with application to shifts in jellyfish distribution. J. Agric. Biol. Environ. Stat. In press.

Massutí, E. and J. Moranta. - 2003. Demersal assemblages and depth distribution of elasmobranchs from the continental shelf and slope off the Balearic Islands (western Mediterranean). ICES J. Mar. Sci., 60: 753-766.

Massutí, E. and O. Reñones. - 2005. Demersal resource assemblages in the trawl fishing grounds off the Balearic Islands (western Mediterranean). Sci. Mar. 69: 167-181.

Maynou, F. and J.E. Cartes. - 2000. Community structure of bathyal decapod crustaceans off south-west Balearic Islands (western Mediterranean): seasonality and regional patterns in zonation. J. Mar. Biol. Assoc. UK, 80: 789-798.

Moranta, J., C. Stefanescu, E. Massutí, B. Morales-Nin and D. Lloris. - 1998. Fish community structure and depth-related trends on the continental slope of the Balearic Islands (Algerian basin, western Mediterranean). Mar. Ecol. Prog. Ser., 171: 247-259.
Moranta, J., E. Massutí, C. Stefanescu, M. Palmer and B. MoralesNin. - 2008a. Short-term temporal variability in fish community structure at two western Mediterranean slope locations. Deep-Sea Res., 55: 866-880.

Moranta, J., A. Quetglas, E. Massutí, B. Guijarro, M. Hidalgo and P. Díaz. - 2008b. Spatio-temporal variations in deep-sea demersal communities off the Balearic Islands (western Mediterranean). J. Mar. Syst., 71: 346-366.

Olaso, I., F. Velasco and N. Perez. - 1998. Importance of discarded blue whiting (Micromesistius poutassou) in the diet of lesser spotted dogfish (Scyliorhinus canicula) in the Cantabrian Sea. ICES J. Mar. Sci. 55: 331-341.

Ordines, F., A. Quetglas, E. Massutí and J. Moranta. - 2009. Habitat preferences and life history of the red scorpion fish, Scorpaena notata, in the Mediterranean. Estuar. Coast. Shelf Sci., 85: 537-546.

Ordines, F. and E. Massutí. - 2009. Relationships between macroepibenthic communities and fish on the shelf grounds of the western Mediterranean. Aquat. Conserv., 19: 370-383.

Relini, G., J.A. Bertrand and A. Zamboni. - 1999. Synthesis of the knowledge on bottom fishery resources in Central Mediterranean (Italy and Corsica). Biol. Mar. Med., 6(Suppl. 1): 94-98.

Rodríguez-Cabello, C., F. Sánchez, A. Fernández and I. Olaso. 2004. Is the lesser spotted dogfish (Scyliorhinus canicula) from the Cantabrian Sea a unique stock? Fish. Res., 69: 57-71.

Sánchez, F. - 1993. Las comunidades de peces de la plataforma del Cantábrico. Pub. Espec. Inst. Esp. Oceanogr., 13.

Sánchez, F., M. Blanco and R. Gancedo. - 2002. Atlas de los peces demersales y de los invertebrados de interés comercial de Galicia y el Cantábrico. Otoño 1997-1999. Madrid: CYAN, Proyectos y Producciones Editoriales.

Stefanescu, C., D. Lloris and J. Rucabado. - 1992. Deep-living demersal fishes in the Catalan Sea (western Mediterranean) below a depth of 1000 m. J. Nat. Hist., 26: 197-213.

Stevens, J.D., R. Bonfil, N.K. Dulvy and P.A. Walker. - 2000. The effects of fishing on sharks, rays, and chimaeras (chondrichthyans), and the implications for marine ecosystems. ICES J. Mar. Sci., 57: 476-494.

Thrush, F. and P. Dayton. - 2010. What can ecology contribute to ecosystem-based management? Ann. Rev. Mar. Sci., 2: 419-441.

Tursi, A., G. D'Onghia, A. Matarrese and G. Piscitelli. - 1993. Observations on population biology of the blackmouth catshark Galeus melastomus (Chondrichthyes, Scyliorhinidae) in the Ionian Sea. Cybium, 17: 187-196.

Valls, M., A. Quetglas, F. Ordines and J. Moranta. - 2011. Feeding ecology of demersal Elasmobranch in the Western Mediterranean. Sci. Mar. 75(4): 633-639.

Wood, S.N. - 2000. Modelling and smoothing parameter estimate with multiple quadratic penalties. J. R. Stat. Soc., B 62(2): 413-428.

Scient. ed.: E. Massutí.

Received May 25, 2010. Accepted February 1, 2011.

Published online August 22, 2011.

This is a contribution to 13th European Elasmobranch Association Conference (Palma, 19-22 Novembre 2009) 